\title{
Intending to legislate
}

\author{
Article
}

Accepted Version

Kyritsis, D. (2015) Intending to legislate. Modern Law Review, 78 (1). pp. 164-175. ISSN 0026-7961 doi:

https://doi.org/10.1111/1468-2230.12111 Available at https://centaur.reading.ac.uk/38958/

It is advisable to refer to the publisher's version if you intend to cite from the work. See Guidance on citing.

To link to this article DOI: http://dx.doi.org/10.1111/1468-2230.12111

Publisher: Wiley

All outputs in CentAUR are protected by Intellectual Property Rights law, including copyright law. Copyright and IPR is retained by the creators or other copyright holders. Terms and conditions for use of this material are defined in the End User Agreement.

\section{www.reading.ac.uk/centaur}

\section{CentAUR}

Central Archive at the University of Reading

Reading's research outputs online 


\title{
INTENDING TO LEGISLATE
}

\author{
Dimitrios Kyritsis*
}

Richard Ekins, The Nature of Legislative Intent, Oxford: Oxford University Press, 2012, xiii+303 pp, hb £36.99

\section{INTRODUCTION}

It is uncontroversial that the legislatures with which we are familiar comprise a multitude of legislators. It is also uncontroversial that legislatures have or claim to have the moral power to change the law. When a legislature exercises this power, it does so through a combination of acts by its members. When that exercise of power is successful, it has an effect on our legal rights and duties. ${ }^{1}$ During the legislative process, legislators form an intention that a specific statute be or not be enacted. This, too, seems to be rather uncontroversial. What has proven a lot more controversial is whether that intention and the various other intentions that legislators entertain in the course of the legislative process determine the statute's effect on our rights and duties, and, if so, how.

In recent decades there has been a revival of jurisprudential research in such issues. On the main, this phenomenon has been driven by two factors. First, legal philosophers have once again begun to ask why and under what conditions the legislature can make a difference to the law. Whereas the function of legislatures has been a traditional object of study for political scientists and constitutional lawyers, it was for a long time assumed that the theory of law can do without paying close attention to them. ${ }^{2}$ Heeding Bismarck's admonition that 'no man should see how laws and sausages are made', the theory

\footnotetext{
* Associate Professor in Law, University of Reading. References to the book are in brackets. I am grateful to Stuart Lakin and Dimitris Tsarapatsanis for discussion of an earlier version and to the editors of the MLR for their comments and suggestions.

1 M Greenberg, 'Legislation as Communication? Legal Interpretation and the Study of Linguistic Communication' in A Marmor and S Soames (eds), Philosophical Foundations of Language in the Law (New York, OUP, 2011) 217, 238: 'a law-making act's success consists in its generating legal obligations'.

${ }^{2}$ Needless to say, it was not always so. To name a notable example, Jeremy Bentham had a keen interest in legislatures, about which he wrote extensively. See J Bentham, An Introduction to the Principles of Morals and Legislation, edited by JH Burns and HLA Hart (London, Methuen, 1970).
} 
of law could presumably focus on the finished product, the statute that was eventually enacted. ${ }^{3}$ Political science's iconoclastic approach to the subject probably corroborated this attitude of distancing. ${ }^{4}$ Things have now changed, as contemporary democratic theory has put the deliberative and legitimating potential of legislative bodies front and centre. ${ }^{5}$

The second factor that has brought legislatures back into the limelight is the increased traffic between legal theory and the philosophy of language. ${ }^{6}$ That is not to say that legal theory had ignored the philosophy of language in the past. After all, language plays a salient role in legal practice. Unsurprisingly, then, as the philosophy of language made strides in recent years, especially in the pragmatics of communication, legal philosophy sought to keep pace. This development is thought to hold special appeal for those who study the legislature. The utterances of the legislature may not be the only jurisprudentially important thing about it, but, unlike the utterances of a court, they are commonly understood to possess a canonical status, making the statutory text a focal point of legal interpretation. Thus many scholars maintain that the general study of language can help us resolve some of the difficulties we encounter in assigning meaning to statutes.

It is against this backdrop that Richard Ekins' new book, The Nature of Legislative Intent, ought to be read and evaluated. The book deserves praise for advancing our thinking about legislative intent on several fronts. Legislatures are collective bodies with a pivotal legal and political role, and they typically decide by enacting texts. So a comprehensive philosophical account must examine them in the light of legal and political philosophy and the philosophy of language and collective action. It must ask: How do individual legislators act as one institution? What authority do they jointly possess? How are the texts they enact to be interpreted in order to yield answers to questions about our legal rights and duties? Ekins astutely engages all these issues. The outcome is a systematic and well-defended view that commands our attention. At the same time, his discussion is firmly grounded in a thorough and confident knowledge of the law and legislative practice. His legal examples are illuminating and varied and drawn from a number of jurisdictions for good

\footnotetext{
${ }^{3}$ It is not certain whether Bismarck made an admonition or observation, or whether Bismarck said anything at all about laws and sausages. Jeremy Waldron, who has done more than anyone to rekindle the jurisprudential study of legislatures, has also addressed this particular exegetical problem in remarkable detail in $\mathrm{J}$ Waldron, Law and Disagreement (Oxford, Oxford University Press, 1999) 88, n 2.

${ }^{4}$ See for instance M Radin.'Statutory Interpretation' (1930) 43 Harvard Law Review 863.

${ }^{5}$ See among others A Gutman and D Thompson, Why Deliberative Democracy (Princeton NJ, Princeton University Press, 2004).

${ }^{6}$ For an overview see Marmor and Soames (eds), Philosophical Foundations of Language in the Law (n 1).
} 
measure. In addition, Ekins does not hesitate to enter specific doctrinal debates concerning statutory interpretation and take sides in them. Consequently, The Nature of Legislative Intent makes for appealing read to the doctrinal lawyer as much as the jurisprudent. I do not hope to offer a comprehensive review of this rich book here. My aim is more limited and focused. After briefly outlining Ekins' main claims I am going to put pressure on one of the connections that undergird his project, that between language and the law.

\section{LEGISLATING TOGETHER}

As mentioned above, legal philosophy was for long inimical to the notion of legislative intent, and probably this stance still sets the tone. Hence, it is only natural that Ekins' positive proposal proceeds dialectically from its confrontation with the critics of legislative intent. Ekins singles out two types of critic. On the one hand, you have sceptics like Ronald Dworkin who, as Ekins interprets them, raise doubts about the very possibility of constructing from the disparate intentions and other psychological states of individual legislators something that could plausibly be called the intention of an institution, the legislature. On the other hand, you have textualists like Jeremy Waldron who claim that statutory interpretation should be guided by the 'plain' meaning of the words of the statute.

Against the former camp Ekins uses contemporary theory of collective action to show that legislative intent is not a fiction. Legislatures routinely form and act on intentions, he maintains. All sorts of groups can do that. His argument to this effect is simple but ingenious. Participation by individual legislators in legislative process has the institutional significance that it does by virtue of the procedures that govern the function of the legislature as a collective body. Otherwise, why think that the fact that a number of people said 'aye' on some particular occasion made it the case that a statute was enacted? Legislators, at least in principle, are aware of those procedures and have a standing intention to contribute to the function of the legislature in the ways specified by them. Once this intention is in place, it is irrelevant that their acts may be individually motivated by further conflicting agendas. They retain their institutional significance as contributions to the legislative process.

A legislature acts when such contributions are combined in the right way. Its act is not an unintentional product of those individual contributions. Rather, it is animated by a 
distinct collective intention. Ekins does not make the modest claim that the content of this intention is solely that a certain bill become law. ${ }^{7}$ Rather, he insists on the stronger claim that the legislature intends to introduce a scheme that represents a reasoned response to an issue of public concern. Ekins analyses the legislative process on the Westminster and Washington models and explains how they are both (though with varying success) animated by the same deliberative aspiration (169ff). On this view, legislative intent can survive what is typically a lengthy sequence of stages each of which may involve different combinations of legislators. Legislative procedure commonly institutes a division of labour, whose outcome legislators can recognize as their collective decision by virtue of their commitment to the procedure. In turn, the procedure is supposed to facilitate that the collective decision will be the outcome of reasoned deliberation.

The defect in the reasoning of the sceptics is that they presuppose an aggregative or summative conception of legislative intent. If you think that legislative intent is an aggregate of the intentions of individual legislators, you will be drawn to scepticism. There is no reason to expect that a sufficiently determinate common denominator can be found in such a large and diverse group. Scepticism also chimes with empirical findings about the extent to which individual legislators are informed and care about the bills that are put to their vote. This is why some sceptics have instead focused on the intentions of a subsection of - especially consequential - legislators, say the sponsors of a bill or the majority that voted for it. Surely, we are more likely to find commonality of purpose among them than among the legislature as a whole. Ekins'strategy obviates the need for this manoeuvre. If a bill's sponsors play a crucial part in the law-making process, it is because they are assigned that part by the master plan that underpins the function of the legislature. So legislators need not be of one mind when they are deciding on a piece of legislation. All that is necessary is that they intend to act together in accordance with the master plan.

The second front on which Ekins defends legislative intent is against textualists. Textualists advocate that statutes should be interpreted according to what they call the "plain meaning' of the words of the statute. By this they often mean their literal meaning. Ekins objects that the plain meaning is in no way a more basic determinant of a statute's meaning. What is basic, he insists, is that the enactment of a statute is a communicative act. Drawing

\footnotetext{
${ }^{7}$ Joseph Raz and John Gardner have both put forward such minimalist conceptions of legislative intent. See J Raz, 'On Intention in Interpretation' in R George (ed), The Autonomy of Law (Oxford, Oxford University Press, 1996) 249, and J Gardner, 'Some Types of Law' in D Edlin (ed), Common Law Theory (Cambridge, Cambridge University Press, 2007) 51.
} 
on work done by Stephen Neale, Scott Soames and others in the philosophy of language, Ekins contends that legislatures, just like language users, communicate by employing semantic as well as pragmatic means, relying - crucially - on context and shared understandings between them and their audience. As a result, much of what they assert through the enactment of a statute goes beyond or qualifies the semantic content borne by the words they use. So, although it makes sense to distinguish semantic content for analytical purposes, it is mistaken to attribute to it any primacy in statutory interpretation. A good interpreter will also attend to those further parameters.

The two sets of claims Ekins advances are mutually supportive. On the one hand, the argument against scepticism establishes the existence of the object of study, namely the collective intent of the legislature, which the argument against textualism presupposes. Conversely, while the latter argument licenses recourse to context for ascertaining the meaning of a statute, this recourse is facilitated by the exploration of legislative process undertaken as part of the former argument. Surely, we can find out a lot about the context of law reform from the legislative process (ministerial statements, legislative debate, etc). And in order to do this effectively, we need to understand how the legislative process enables and structures the joint activity of the legislature.

\section{THE AUTHORITY OF LEGISLATION AND THE CONTENT OF THE LAW}

I shall not be concerned with assessing the success of Ekins' response to the various types of scepticism about legislative intent. In particular, I do not intend to explore whether he succeeds in steering clear of aggregative notions of legislative intent or he merely postpones the reckoning with them. ${ }^{8}$ Instead, I want to criticize the connection he draws between his vision of legislatures and the content of the law. I shall argue that Ekins assumes a controversial picture of the way facts about the doings and sayings of legislators as a collective body impact on our legal rights and duties. To bring this out, I shall juxtapose his approach to a different one, which draws on the anti-positivist tradition, more specifically the legal philosophy of Ronald Dworkin. I shall draw this contrast, not because I shall have much

\footnotetext{
${ }^{8}$ This is the focus of Jeffrey Goldsworthy's review of Ekins' book. See J Goldsworthy, 'Legislative Intention Vindicated?' (2013) OJLS 821-842
} 
novel to say about anti-positivism or Dworkin, but because by doing so I want to open up a possibility relevant to our topic that Ekins' basic assumptions seem to foreclose. With our options thus expanded, in the next section I shall evaluate some of Ekins' concrete proposals about statutory interpretation.

What is the character of Dworkin's scepticism about legislative intent? On one reading, which Ekins seems to share, it is metaphysical. Dworkin argues that there are many choices that we would have to make to construct the intention of the legislature from a set of historical facts, choices between different psychological states that different sets of legislators entertained during the legislative process, their abstract and concrete intentions regarding the interpretation of the statute they enacted, and so on. However, there is no 'shared concept of intention, 9 no 'legal linguistic convention', ${ }^{10}$ which will govern these choices. Under these circumstances, we have to conclude that legislative intent does not exist. ${ }^{11}$ In this picture, moral values are a deus ex machina that we invoke to fill the void. What we would seek in vain as a matter of historical fact we turn into a question about which imputation of intent would be morally appealing. In a passage on constitutional interpretation that seems to encourage this reading, Dworkin warns against supposing that the intention of the Framers is 'some complex psychological fact locked in history waiting to be winkled out from old pamphlets and letters and proceedings. But this is a serious common mistake, because there is no such thing as the intention of the Framers waiting to be discovered, even in principle. There is only some such thing waiting to be invented'. ${ }^{12}$

Now, were this Dworkin's view, it would perhaps make sense to respond to him by exploring the ontology of collective intent. If Ekins is right that there is a (fairly) determinate concept of collective intention that applies to the legislature, then the recourse to morality that Dworkin champions becomes redundant. However, there is a different way of understanding Dworkin's scepticism. On this alternative reading, his scepticism is underpinned by the following general philosophical conviction: legal obligations are a species of moral obligation. Therefore, they do not exist unless there is a moral justification of the right sort for them. Their content is determined by the principles of political morality

\footnotetext{
${ }^{9} \mathrm{R}$ Dworkin, 'The Forum of Principle' in R Dworkin, A Matter of Principle (Cambridge, MA, Harvard University Press, 1986) 41.

${ }^{10}$ Ibid.

${ }^{11}$ I am taking for granted that absence of some sort of agreement along the lines suggested by Dworkin would have the radical consequence that legislative intent does not exist. This is a controversial view, but it goes beyond this paper to evaluate it.

${ }^{12} \operatorname{Ibid} 39$.
} 
that best fit and justify past political history. Political history includes legislative decisions. So legislative decisions are meant to constrain the selection of moral principles. It counts against a certain moral principle being determinative of our legal obligations that it does not do a good job at fitting and justifying those decisions and vice versa. Take democracy. Democracy can explain why the decision of a democratically elected legislature must have a strong impact on our legal obligations. ${ }^{13}$ But it does more than that. It can also explain what impact it has. A full-blown theory of democracy selects from among the various events constituting the legislative process those that have a role in creating legal obligations. Furthermore, it can determine what that role is. It can thus guide our more particular judgments about the bearing of the legislative process on the content of the law by supplying a yardstick for choosing between interpretive solutions. If one solution would serve democracy better than another and would thus make it morally right that we have this or that legal obligation, then it is ceteris paribus more sound as an account of the content of the law. For instance, it could be said that democracy furnishes a reason for paying close attention to those stages of the decision-making process that possess high deliberative credentials and use the debate at those stages as an interpretive tool.

Democracy is just one of the candidate principles that may play a role in determining the impact of a legislative decision on our legal obligations. There are others. Crucially, there are those principles that set substantive limits to what the legislature may do. For instance, Dworkin has famously argued that a legal obligation exists only if having it satisfies the demands of political integrity, which provides that all citizens must be treated according to the same conception of equal concern and respect. Thus, the fact that a legislative decision flouts integrity undercuts its effect on the law, no matter what legislators thought or intended. Besides, Dworkin's account gives us no reason to view legislative decisions in isolation. ${ }^{14}$ It does not suppose 'a fixed moment when the statute was spoken,

\footnotetext{
${ }^{13}$ You may think that there are other considerations, which make it the case that the decisions of a nondemocratic legislature can also change our legal obligations. So, for instance, Ekins does not preclude that '[i]n communities that would otherwise lack the rule of law, it is...reasonable to authorize one person to legislate, to be a prince' (144). Moreover, you may think that democracy performs at best a secondary role in justifying the authority of even representative law-making institutions. These are substantive moral judgments that do not affect my argument. I mention democracy solely to give the general flavour of the way moral values ground legal obligations on the Dworkinian story. Ekins includes a very interesting defence of the authority of democratically elected, multi-member legislative assemblies in chapter 6.

${ }^{14}$ By contrast, as we shall see below, Ekins thinks that, when the legislature acts as it was supposed to, it repeals or introduces into the law the propositions that it had intended to repeal or introduce. For him, then, we can study this effect of legislative decisions on our legal rights and duties independently of any further effects they may have, perhaps in combination with the decisions of other bodies. This is the position that Dworkin rejects.
} 
when it acquired all the meaning it ever has'. ${ }^{15}$ Political morality may instruct us to view statutes instead in conjunction with other events, including other political decisions, of the same body and other bodies.

Against this background, it becomes easier to understand Dworkin's dismissal of legislative intent. The difficulties he identifies with making this notion determinate are symptomatic of what is for him a deeper philosophical mistake and are meant to pave the way for his preferred alternative. The mistake is to think that historical facts about what some people have said and done can by themselves determine the content of the law. For Dworkin it is ultimately moral facts that justify us having a legal obligation. ${ }^{16}$ They give legislatures what authority they have and they specify how that authority is successfully exercised; they also place limits on that authority. ${ }^{17}$ Consequently, values also steer statutory interpretation: we interpret statutes in light of the authority contained in the process that enacted them and all the other relevant moral considerations that explain and justify political history. This does not mean that we have to discard the term 'legislative intent' altogether. But we must bear in mind that on this view the term does not refer solely to historical facts about what legislators said and did. Rather, it is something of a shorthand for the effect of those sayings and doings on the content of the law with the inescapable mediation of moral principles. We must also bear in mind that this effect may be qualified by considerations that have little to do with what the legislature has said and done at all. Thus, what Dworkin objects to is not legislative intent itself, but rather the idea that legislative intent is a notion 'fixed in history independent of our opinions about proper legal or constitutional practice'. ${ }^{18}$ To criticize Dworkin's dismissal of legislative intent on the narrow front that the notion of legislative intent can be rendered determinate loses sight of this broader battle.

Dworkin's theory of law, we have seen, assigns moral facts a central role in the determination of the content of the law. It thus lies in stark contrast to the theory that underlies Ekins' project. There, moral facts make a much more modest and clearly delimited contribution to the determination of the content of the law. For Ekins, one of the defining characteristics of law is that it 'authorizes some person or body to modify the system by changing one or more of its component rules, or at least changing the application, or likely

\footnotetext{
${ }^{15}$ R Dworkin, Law's Empire (Oxford, Hart Publishing, 1998) 316.

${ }^{16}$ Ekins shares this view. What differentiates him from Dworkin, as we shall see below, is the way he takes moral facts to justify legal obligations.

${ }^{17}$ Dworkin, 'The Forum of Principle', (n 9) 35-36.

${ }^{18}$ Ibid 39.
} 
application, of one or more of those rules' (118-9). Morality tells us that this characteristic makes law 'a valuable form of social order' (118), because it enables a political community to adapt to new circumstances or to moral discovery. When it is in good shape, the legislature is the right body to be entrusted the role of deliberately affecting our rights and duties through its decisions. This claim, too, is grounded in a normative argument concerning comparative institutional capacity, namely that the legislature is 'an institution that is free to deliberate and to act as and when it chooses' (125) and can draw up a 'complex, comprehensive decision as to what shall be done' (125). ${ }^{19}$ Finally, political morality recommends that the legislative body be an assembly of elected representatives rather than a sole legislator, even if the latter is elected. That is because an assembly better combines the virtues of representation and deliberation (146-53), ${ }^{20}$ and can thus avoid the problems of tyranny, exclusion and incompetence that beset the sole legislator system (143-6).

At this stage, however, social ontology takes over from political morality. The well-formed legislative assembly exercises its authority by balancing the reasons regarding the need for deliberate legal change. It then typically produces a response in the form of a decision to set up a regulatory scheme that is supported by the balance of reasons. But the existence and content of that response does not depend on morality. It is a social fact. The same goes for determining the meaning of the response. To do this, we only need to attend to facts about communication. These are likely to be complex facts, but their complexity is not moral. What we want to know is what the legislature intended to communicate, not what it ought to have communicated.

This last claim about statutory interpretation is premised on two crucial assumptions. First, remember that the legislature's reasoned choice goes beyond the text it enacted to formulate that choice. If we are to maintain the sharp divide between moral and factual inquiry, we must suppose that we can reconstruct the elements of that choice that are extraneous to the text without recourse to moral argument about what that choice ought to be and what elements ought to inform it. Even if we take as a given that the rules governing legislative procedure can be applied without recourse to morality, we are still faced with the

\footnotetext{
${ }^{19}$ From this Ekins also derives a further argument against textualism. If the role of the legislature is to produce a reasoned choice to an issue of common concern, it would vitiate that role to make the text of the statute the object of legislative intent. The choice cannot be equated with the text but goes beyond and qualifies it.

${ }^{20}$ For a parallel argument grounding legislative authority see D Kyritsis, 'Constitutional Review in Representative Democracy' (2012) 32 OJLS 297-324.
} 
uphill task of inferring from the unfolding of a complex political process a fairly determinate picture of a means-ends scheme, complete with underlying reasons.

As already indicated, I do not intend to take issue with this aspect of Ekins' view. More relevant for my purposes is a different assumption made by Ekins, namely that a change in the law comes about just in case the legislature as a collective body intends that change and communicates its intention in the appropriate way. Arguably, this is what the authority of the legislature consists in, to create legal obligations by mere say-so. To use Mark Greenberg's terminology, there is an explanatorily direct link between the communicating of the intention and the obtaining of the legal obligation. ${ }^{21}$ The communication of the intention does not explain something else, which then gives rise to the duty. That would be the case, for instance, if the communication of the intention created a legitimate expectation that a certain obligation will be enforced or gave salience to a certain solution to a coordination problem. For simplicity, I am going to use the concept of 'explanatory directness' in what follows to denote this close connection between intention and the content of the law. As already noted, Dworkin rejects explanatory directness. As a result, he leaves it open that the principles of political morality that ultimately determine the content of the law may modify or even cancel the change in the law that the legislature had intended to bring about.

Ekins, by contrast, seems to embrace explanatory directness. In the following characteristic passages, he writes: 'To change the law is to change the set of propositions that constitute the law... [A] law is a prescription of practical reason promulgated by a legal authority' (125, emphasis added). '[T] he enactment of a statutory text...promulgates the legislator's choice, his decision, that certain [legal] propositions are to be repealed or introduced' (128). He adds: 'The legislator acts to legislate when he communicates or promulgates his choice that certain propositions shall be law. The form of the choice is the statutory text and the act of enactment is thus both the adoption of the text as law and, more importantly, the exercise of authority to introduce into the law the propositions of which the text is a formulation' (136). Elsewhere he writes: 'The exercise of legislative authority is the making and promulgation of a choice. This truth frames how the legislature's act changes the law. The legislature forms and acts on intentions, which it acts to make publicly known, and what the legislature adopts and promulgates is thereby transformed from a proposal to law'

\footnotetext{
${ }^{21}$ M Greenberg, 'The Standard Picture and its Discontents' in L Green and B Leiter (eds), Oxford Studies in Philosophy of Law: Volume 1 (Oxford, Oxford University Press, 2011) 39.
} 
(247). Note that this is far from a peripheral aspect of Ekins' project. His entire analysis is geared towards constructing a conception of legislative intent that can help us determine the meaning of a statute, by which we cannot but mean its legal meaning. In turn, its legal meaning is nothing other than its effect on the content of the law, the legal propositions that it 'repeals or introduces'.

As stated earlier, everybody agrees that statutes typically have an effect on the content of the law. It is debatable, though, whether they do so in the way presupposed by Ekins. That legislatures can form group intentions and that they intend to legislate, even if true, does not settle the matter. This is so for two reasons. First, we cannot exclude the possibility that, when the legislature intends to legislate, it has a relatively modest intention, that is, merely to contribute to the content of the law, knowing full well that the effect of this contribution is subject to further considerations, like the moral ones that Dworkin puts in the driving seat. According to this possibility, the legislature does not have the further stronger intention to repeal or introduce legal propositions by say-so. Second, assuming that the legislature's intentions are not modest, why should they themselves determine what effect they have on the law? ${ }^{22}$ Ekins writes that they are 'at least closely relevant to the legal changes the act should be understood to introduce' (11). But there must be an explanation that bestows on them this role. Many morally important - including some legal consequences are independent of anyone's intentions, so it takes further argument to show that in this particular case our obligations closely track the intentions of the legislature. In addition, it is highly unlikely that this explanation can be found in the philosophy of language. No doubt, when legislators enact a statute, they engage in a form of communication. But the enactment of a statute affects our rights and duties not because it is an act of communication but because it is an exercise of authority.

Thus, to defend explanatory directness we must consult political philosophy and the theory of practical reason. There is no shortage of views that take this tack. For instance, Joseph Raz argues that the task of practical authorities (among which he counts law) is to issue a directive that reflects their view about what authority subjects ought to do to comply with reasons that apply to them. According to the logic of authoritative guidance, authority

\footnotetext{
${ }^{22} \mathrm{~N}$ Stavropoulos, 'Obligations, Interpretivism and the Legal Point of View' in A Marmor, The Routledge Companion to Philosophy of Law (New York, Routledge, 2012) 76.
} 
subjects have a reason to treat that view as binding. ${ }^{23}$ Similarly, David Enoch proposes that practical authorities could be understood to create a special kind of reason which he labels robust. Robust reasons have the following structure: In the relationship between authority and subject, the authority intends to give the subject a reason to $\varphi$ and communicates this intention to her, intending that the subject recognizes this intention and that the reason will depend in an appropriate way on that recognition. In these and other similar circumstances robust reasons are created 'merely by the very forming of the intention to give a reason'. ${ }^{24}$

Ekins does not explicitly align himself with any such view, but the same spirit animates his argument. As already discussed, it proceeds from an analysis of the concept of legislating. Legislating, he argues, is meant to be a rational activity. Ideally, it is guided by judgments about what is good for society and about the means to achieve it. These judgments are governed by right reason. Ekins contends that the legislature has authority insofar as it engages in this form of rational activity. Its authority consists in enacting into law the regulatory scheme it has judged follows from right reason.

However, the evidence offered falls short of establishing the explanatory direct link Ekins draws between legislative action and legal authority. All it shows is that the intention of the legislature, if there is such a thing, is to exercise a legal power understood in a certain way. What it does not show is that the change in the law effected by a statute is the meaning of the proposition asserted by the legislature in enacting it. We can accept that the legislature's contribution to the content of the law is a reasoned choice for the promotion of the common good rather than a mere text and still doubt that we can calculate its legal meaning solely by interpreting what it meant to convey. We have noted two possibilities that fuel this doubt. To begin with, as the legislature is not the only body that speaks on law's behalf, it seems plausible to suggest that, in order to ascertain its contribution to the law, we ought to examine the interplay between the legislature and the other main players in the constitutional order. The latter may have the power to alter or temper the impact of a statute. (I shall give an example of this in the next section.) Furthermore, it is arguable, as some natural lawyers think, that legal authority only exists within certain moral limits, and hence a

\footnotetext{
${ }^{23}$ See generally J Raz, 'Authority, Law and Morality' in Ethics in the Public Domain (Oxford, Clarendon Press, 1994) ch 10. Interestingly, Raz defends a version of the plain meaning view of statutory interpretation but he does so primarily on the basis of a theory of linguistic communication that Ekins takes issue with. See J Raz, 'Intention in Interpretation' in Between Authority and Interpretation (Oxford, Oxford University Press, 2009) ch 11.

${ }^{24}$ D Enoch, 'Authority and Reason-Giving' (2012) Philosophy and Phenomenological Research 1, 7 doi: $10.1111 / j .1933-1592.2012 .00610 . x$
} 
legislative decision that violates these limits has no effect on the law, regardless of how reasoned it is. Here, again, the contribution of the legislative decision to the content of the law is not exclusively a function of what the legislature intended.

If you subscribe to Dworkin's brand of anti-positivism, you will be attracted to both of these possibilities. To decide between the Dworkinian view and Ekins', you will have to engage head-long with philosophical debates about the nature and determinants of legal obligation. Ekins does not win by default.

\section{MORALITY AND STATUTORY INTERPRETATION}

In the previous section I contrasted two accounts of the connection between legislative utterances and the content of the law. However, it might seem to some that this contrast is rather abstract and disconnected from the practical concerns of those who invoke and study legislative intent. Does it make any difference in statutory interpretation? I think it does. To show this, I shall use two illustrations. Notice, first, that the contrast sheds new light on Ekins' critique of textualism. Ekins argues against textualists using resources and insights borrowed from the philosophy of language. Dworkin's theory of law cuts across this dispute. On Dworkin's theory, the truth or falsity of textualism ultimately rests on the moral case that can be made for it, and not solely on facts about language and communication. In fact, regardless of how it is presented by its advocates, textualism itself can be defended on moral grounds. In the circumstances of democratic politics, it can be said, the enactment of a statute is achieved in the midst of reasonable disagreement about moral issues. Hence, by interpreting the statute on the basis of the plain meaning of the enacted text, we are vindicating that achievement because arguably we insulate it from the controversy from which it emerged. Or maybe we are promoting the value of publicity or fair notice. Note that this construal of textualism makes no reference to the idea that the plain meaning of the words of the statute more accurately conveys legislative intent. Rather, it is based on moral considerations about how the legal effect of legislative decisions ought to be cashed out. Needless to say, some of Ekins' careful arguments could also be understood to undercut the moral case for textualism. Perhaps they establish that the plain meaning is too indeterminate to serve the value of fair notice or the asserted meaning sufficiently public to perform the 
same task. It goes beyond the scope of this article to assess the merits of the arguments for and against textualism. The foregoing thoughts were solely meant to demonstrate that the Dworkinian outlook on statutory interpretation changes the terms of that debate.

A further illustration of the practical purchase of the Dworkinian alternative is to do with presumptions of statutory interpretation (259ff). Such presumptions are underlain by 'legal principles that form part of the constitutional order' (259) about what a good legislator would do. Generally speaking, Ekins' strategy is to fold interpretive presumptions into the context which informs our inferences about 'what the legislature is likely to intend' (260). This is an unstable strategy because it cannot but be a contingent and highly uncertain matter whether the legislature really intended what is good, whereas the presumption tips the scale significantly - and in many cases decisively - in favour of this scenario. More basically, though, Ekins' strategy only makes sense if we believe that the rights and duties that a statute creates are those that the legislature actually intended, in the appropriate sense, to create.

By contrast, if we reject this belief, as Dworkin does, we do not need to rely on a morally beefed up notion of legislative intent. Instead, we can say that the bearing of a legislative decision on our rights and duties is checked by other principles of political morality. These operate independently of whether any legislator thought of them when enacting the statute or endorsed them. They operate just by virtue of the fact that they contribute to the appropriate moral case for the existence of a legal obligation. Consider the presumption that Parliament does not intend to legislate contrary to human rights. Dworkin would say that it imposes a moral constraint on what rights and duties can flow from a statute, grounded solely in the importance of human rights principles as determinants of legal obligation (in this or that jurisdiction), rather than reflecting a dubious standing disposition of legislators, individually or collectively, to respect these principles. In turn, the power of Parliament to overturn the presumption through the use of clear and unambiguous language can be seen to be grounded in the (controversial) proposition that the value of democratic self-rule sometimes overrides human rights principles.

Besides, it is important to remember that such presumptions are typically employed by law-applying institutions such as courts in the course of interpreting primary legislation. They can thus be understood as a further obstacle to explanatory directness. They dramatize the possibility adumbrated above that, in order to determine the change in the law brought about by a piece of legislation, it is not enough to look at facts about the legislative 
process that led to its adoption but must take into account facts about other state institutions like courts as well as facts about what the legislature had decided in the past. ${ }^{25}$ As Dworkin puts it, 'the history [the judge] interprets begins before a statute is enacted and continues to the moment when he must decide what it now declares'. ${ }^{26}$

\section{CONCLUSION}

The Nature of Legislative Intent is an in-depth study of legislatures that offers thoughtful solutions to age-old jurisprudential quandaries. It also puts much needed philosophical sophistication at the service of constitutional law and legal interpretation more generally. This is a book driven by the insight that legislative intent is a concept connecting the inquiry about how legislatures are constituted, and how they act and speak, with the inquiry about how they change the law. But we must be mindful of the fact that the first inquiry is largely factual while the other normative. In order to bridge the two, as I have sought to show in this article, our accounts of legislative intent must attend to the role that the legislature plays within the broader legal order, the way in which it is meant to contribute to the law. At this level, we must factor into our account a wide range of considerations that arguably qualify the bearing of legislative decisions on the content of the law. We must also take a stand on questions regarding legal authority and the grounds of legal obligation. There, we will find yet more quandaries to solve.

\footnotetext{
${ }^{25}$ I would argue that this function of interpretive rules can be detected in the jurisprudence surrounding the application of s 3 of the HRA 1998 by UK courts. See for example Ghaidan v. Godin-Mendoza [2004] UKHL 30. For further analysis see R Ekins and P Sales, 'Rights-Consistent Interpretation and the Human Rights Act 1998' (2011) 127 Law Quarterly Review 217, A Kavanagh, 'Parliamentary Intent, Statutory Interpretation and the Human Rights Act 1998' (2006) OJLS 179.

${ }^{26}$ Dworkin, Law's Empire, (n 15) 316.
} 